\title{
Prognostic Value of Circulating Inflammatory Cells in Patients with Stable and Acute Coronary Artery Disease
}

\author{
John A. L. Meeuwsen ${ }^{1}$, Marian Wesseling', Imo E. Hoefer ${ }^{2}$ and Saskia C. A. de Jager ${ }^{1,3 *}$ \\ ${ }^{1}$ Laboratory for Experimental Cardiology, University Medical Center Utrecht, Utrecht, Netherlands, ${ }^{2}$ Laboratory for Clinical \\ Chemistry and Hematology, University Medical Center Utrecht, Utrecht, Netherlands, ${ }^{3}$ Laboratory of Translational \\ Immunology, University Medical Center Utrecht, Utrecht, Netherlands
}

\section{OPEN ACCESS}

Edited by:

Frederic P. T. Kontny, Stavanger University Hospital,

Norway

Reviewed by:

Maurizio Acampa,

Azienda Ospedaliera Universitaria

Senese, Italy

Ismail Dogu Kilic,

Pamukkale University, Turkey

*Correspondence:

Saskia C. A. de Jager

s.c.a.dejager@umcutrecht.nl

Specialty section:

This article was submitted to General

Cardiovascular Medicine,

a section of the journal

Frontiers in Cardiovascular Medicine

Received: 17 March 2017 Accepted: 26 June 2017

Published: 14 July 2017

Citation:

Meeuwsen JAL, Wesseling $M$, Hoefer IE and de Jager SCA (2017)

Prognostic Value of Circulating Inflammatory Cells in Patients with Stable and Acute Coronary Artery

Disease.

Front. Cardiovasc. Med. 4:44. doi: 10.3389/fcvm.2017.00044
Atherosclerosis is a lipid driven chronic inflammatory disease underlying the majority of ischemic events such as myocardial infarction or stroke. Clinical management of ischemic events has improved considerably in the past decades. Accordingly, survival rates have increased. Nevertheless, $12 \%$ of patients die within 6 months after the initial event. To improve secondary prevention, appropriate risk prediction is key. However, up to date, there is no clinically available routine marker to identify patients at high risk for recurrent cardiovascular events. Due to the central role of inflammation in atherosclerotic lesion progression and destabilization, many studies have focused on the role of circulating inflammatory cells in these processes. This review summarizes the current evidence on the potential of circulating inflammatory cells as biomarkers for recurrent adverse manifestations in acute coronary syndrome and stable coronary artery disease patients.

Keywords: inflammatory cells, coronary artery disease, biomarkers, acute coronary syndromes, stable coronary artery disease, circulating cells, follow-up

\section{INTRODUCTION}

Cardiovascular disease (CVD) remains one of the most important causes of death worldwide. It represents a major challenge in healthcare and it is estimated that $\sim 17.5$ million people die from CVD annually. Although treatment and interventional options have significantly improved survival rates, consequently the incidence of chronic CVD is expected to increase in the next decades (1). Currently, approximately $90 \%$ of patients that encounter a first myocardial infarction (MI) survive (2). However, the risk of secondary cardiovascular manifestations is high. Roughly $5-15 \%$ of patients die during hospitalization or within 30 days after MI (3-5) and an additional 5\% of patients die within 6 months upon hospital discharge (6). The risk of re-infarction is most profound within the first year, occurring in approximately $17 \%$ of patients (7), and the risk for recurrent adverse events further increases over time (8).

Atherosclerosis is the culprit pathology driving coronary artery disease (CAD) and is characterized by the presence of lipid and inflammatory cells during initiation, progression and destabilization of an atherosclerotic plaque (9-11). Monocytes and macrophages are well known for their role in plaque growth. Monocytes transmigrate through the disrupted endothelium and infiltrate the intimal area, where they mature into macrophages. By phagocytosis of oxidized LDL, they develop into foam 
cells which form an integral part of atherosclerotic plaques (12). Next to monocytes, neutrophils, mast cells, and (activated) lymphocytes massively accumulate in rupture-prone regions of the atherosclerotic plaques, suggesting an important role in plaque destabilization (13-15). As the atherosclerotic lesion progresses, necrotic cell death occurs, a process that promotes further lesion progression as it contributes to the inflammatory response and enlargement of the necrotic core, which cumulatively can result in plaque rupture (16-18). Whether the process of necrosis in the plaque directly alters the circulating inflammatory cells profile has, to the best of our knowledge, not been established. Acute coronary syndromes (ACSs) can result in obstructed blood flow, with myocardial necrosis and inflammation as a consequence. In response, the circulating cell profile is altered and inflammatory cells are actively requited to the damaged myocardial tissue (16).

Given their prominent role in CVD, the sheer number of circulating inflammatory cells and their distribution into subpopulations may have predictive value for recurrent cardiovascular manifestations. As such, they can be used to improve risk stratification on top of existing prediction models [i.e., Global Registry of Acute Coronary Events (GRACE) risk score or the Thrombolysis in Myocardial Infarction (TIMI) risk score for ACS patients] (19). Identifying patients at high risk may help to prevent the occurrence of re-infarction or death.

Many studies have studied circulating inflammatory cells as markers of recurrent adverse manifestations after MI. Therefore, we aimed to provide an overview on the value of circulating inflammatory cells as markers for secondary events and mortality in stable CAD and ACS patients.

\section{THE PROGNOSTIC VALUE OF CIRCULATING INFLAMMATORY CELLS IN CAD}

We have included studies that prospectively examine the predictive value of total white blood cell (WBC) count and WBC subtype count or ratios in patients with CAD or ACS specifically. The primary endpoints include major adverse cardiovascular events (MACE) or mortality.

\section{WHITE BLOOD CELLS}

It is generally acknowledged that a high WBC count roughly reflects an activated inflammatory status of an individual. It is well known that people with inflammatory or autoimmune disorders have an increased risk of CVD (20-22), which is most likely the consequence of inflammatory responses negatively affecting plaque stability (23). Therefore, WBC count is well studied during the past decades in CAD patients. Although total WBC was not associated with plaque progression in one study (24), it has been associated with presence, severity, and extent of coronary atherosclerosis in another study (25), as well as with in-stent restenosis in PCI patients (26). The prognostic value of total WBC count in CAD patients is not consistent (Tables $\mathbf{1}$ and $2)$. On one hand, an elevated WBC count $(>8.2 \times 10 \mathrm{e} 9 / \mathrm{L})$ has been independently associated with risk of adverse events and mortality (2.2-fold increase on average) (27-36), but on the other hand, others show no independent predictive value of total WBC count in patients with CAD (37-43). These different findings might be explained by the fact that WBC count independently prognosticated outcome primarily in studies conducted on PCI patients, containing a mixed population of both acute and stable CAD (Tables 1 and 2). More specific prognostic information for risk of follow-up events or mortality might be derived from the WBC differential, since the different WBC subtypes have distinct roles in immune (dis)balance.

\section{MONOCYTES}

Plaque macrophages derive from infiltrating monocytes and are well known for their role in atherosclerotic initiation and development $(24,51,52)$. Distinct monocyte subsets exist

TABLE 1 | Mortality predicted by total white blood cell (WBC) and WBC differential in coronary artery disease (CAD) patients categorized by follow-up time.

\begin{tabular}{|c|c|c|c|c|c|c|c|c|c|c|c|c|c|}
\hline \multicolumn{3}{|c|}{ Study characteristics } & \multicolumn{2}{|l|}{ WBC } & \multicolumn{2}{|c|}{ Monocytes } & \multicolumn{2}{|c|}{ Neutrophils } & \multicolumn{2}{|c|}{ Lymphocytes } & \multicolumn{2}{|c|}{$\begin{array}{c}\text { Neutrophil to } \\
\text { lymphocyte ratio }\end{array}$} & \multirow[t]{2}{*}{ Reference } \\
\hline Population & FU & Size $(n)$ & $\begin{array}{c}\text { Risk } \\
{[95 \% \mathrm{Cl}]}\end{array}$ & $p$ & $\begin{array}{c}\text { Risk } \\
{[95 \% \mathrm{Cl}]}\end{array}$ & $p$ & $\begin{array}{c}\text { Risk } \\
{[95 \% \mathrm{Cl}]}\end{array}$ & $p$ & $\begin{array}{c}\text { Risk } \\
{[95 \% \mathrm{Cl}]}\end{array}$ & $p$ & $\begin{array}{c}\text { Risk } \\
{[95 \% \mathrm{Cl}]}\end{array}$ & $p$ & \\
\hline $\mathrm{PCl}$ & $<1$ & 309 & $1.2[1.0-1.3]^{\mathrm{b}}$ & * & & & & & & & & & (27) \\
\hline $\mathrm{PCl}$ & $1-6$ & 1,425 & $4.8[1.3-16.8]$ & n.s. & $1.7[1.0-2.9]$ & n.s. & 5.7 [1.6-19.6] & n.s. & & & $5.6[1.6-19.8]$ & $* *$ & (40) \\
\hline $\begin{array}{l}\text { UAP/NSTEMI } \\
\mathrm{PCl}\end{array}$ & $\begin{array}{l}>36 \\
>36\end{array}$ & $\begin{array}{r}275 \\
1,425\end{array}$ & $\begin{array}{l}1.7[1.1-2.5] \\
1.7[1.0-2.7]\end{array}$ & $\stackrel{*}{\text { n.s. }}$ & $2.0[1.2-3.4]$ & * & $2.0[1.2-3.3]$ & n.s. & $0.6[0.4-0.9]$ & n.s. & $3.0[1.8-5.0]$ & $* \star \star$ & $\begin{array}{l}(34) \\
(40)\end{array}$ \\
\hline
\end{tabular}

The risk of mortality in CAD patients categorized by follow-up time. The indicated risk can be a relative risk, odds ratio, or hazard rate. Unless stated otherwise, the indicated risk regards the risk of patients in the group with the highest cell count compared to patients with low cell counts. FU indicates follow-up time in months.

${ }^{a}$ Risk regarding cell percentage.

${ }^{b}$ Risk increase per $1 \times 10$ e 9 cells per liter of blood.

${ }^{c}$ Risk was also not significant for neutrophil percentage.

Significance in multivariate analyses is indicated by ${ }^{*} p<0.05$; ${ }^{* *} p<0.01$; ${ }^{* *} p<0.001$; n.s. indicates not significant. 
TABLE 2 | Cardiovascular events predicted by total white blood cell (WBC) and WBC differential in CAD patients categorized by follow-up time.

\begin{tabular}{|c|c|c|c|c|c|c|c|c|c|c|c|c|c|}
\hline \multicolumn{3}{|c|}{ Study characteristics } & \multicolumn{2}{|l|}{ WBC } & \multicolumn{2}{|c|}{ Monocytes } & \multicolumn{2}{|c|}{ Neutrophils } & \multicolumn{2}{|c|}{ Lymphocytes } & \multicolumn{2}{|c|}{$\begin{array}{l}\text { Neutrophil to } \\
\text { lymphocyte ratio } \\
\text { (NLR) }\end{array}$} & \multirow[t]{2}{*}{ Reference } \\
\hline Population & FU & Size $(n)$ & $\begin{array}{c}\text { Risk } \\
{[95 \% \mathrm{Cl}]}\end{array}$ & $p$ & $\begin{array}{c}\text { Risk } \\
{[95 \% \mathrm{Cl}]}\end{array}$ & $p$ & $\begin{array}{c}\text { Risk } \\
{[95 \% \mathrm{Cl}]}\end{array}$ & $p$ & $\begin{array}{c}\text { Risk } \\
{[95 \% \mathrm{Cl}]}\end{array}$ & $p$ & $\begin{array}{c}\text { Risk } \\
{[95 \% \mathrm{Cl}]}\end{array}$ & $p$ & \\
\hline AP & $1-6$ & 1,125 & $2.8[1.9-4.3]$ & $\star \star \star$ & & & $2.5[1.6-3.7]$ & $\star \star \star$ & & & $1.7[1.1-2.5]$ & $\star \star$ & (33) \\
\hline CAD & $>6-36$ & 389 & $1.3[0.6-2.8]$ & n.s. & $1.6[1.1-2.5]$ & * & $1.3[0.7-2.3]$ & n.s. & $0.8[0.5-1.4]$ & n.s. & & & $(42)$ \\
\hline IS/MI/PAD & $>6-36$ & 18,558 & $1.4[1.3-1.6]$ & $\star \star \star ~$ & $1.2[1.1-1.4]$ & $\star \star$ & $1.5[1.3-1.7]$ & $\star \star \star$ & $1.0[0.9-1.2]$ & n.s. & & & (30) \\
\hline $\mathrm{AP}$ & $>6-36$ & 1,125 & $2.5[1.7-3.7]$ & $\star \star \star \star$ & & & $2.3[1.6-3.4]$ & 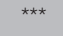 & & & 1.6 [1.1-2.3] & * & (33) \\
\hline $\mathrm{PCl}$ & $>6-36$ & 140 & $34.0[4.1-281]$ & $\star \star$ & & & & & $37.5[4.5-311]^{a, d}$ & $\star \star \star$ & & & (28) \\
\hline $\mathrm{PCl}$ & $>6-36$ & 83 & $10.9[2.4-49.7]$ & $\star *$ & & & & & & & & & (29) \\
\hline PCI SVG & $>6-36$ & 530 & $1.2[1.1-1.3]^{c}$ & 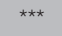 & & & & & & & & & (32) \\
\hline UAP/NSTEMI & $>6-36$ & 280 & $1.3[0.7-2.3]$ & n.s. & & & & & & & & & $(41)$ \\
\hline ACP neg & $>6-36$ & 975 & NR & n.s. & NR & n.s. & NR & n.s. & $2.5[1.3-4.8]^{\mathrm{d}}$ & 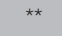 & & & (39) \\
\hline Stable CAD & $>6-36$ & 422 & $2.1[1.0-4.4]$ & n.s. & & & $1.8[0.9-3.8]^{\mathrm{e}}$ & n.s. & & & NR & n.s. & (38) \\
\hline Angiography & $>6-36$ & 951 & & & $3.0[1.3-6.9]^{g}$ & ** & & & & & & & $(45)$ \\
\hline CAD & $>6-36$ & 263 & & & $4.0[1.3-12.1]^{\mathrm{b}}$ & * & & & & & & & (46) \\
\hline Stable CAD & $>6-36^{i}$ & 141 & & & & & & & $1.7[0.8-3.4]^{\mathrm{a}}$ & n.s. & & & $(47)$ \\
\hline UA & $>6-36$ & 120 & & & & & & & $3.0[1.1-8.3]^{\mathrm{h}}$ & * & & & (48) \\
\hline Angiography & $>6-36$ & 3,005 & & & & & & & & & $1.6[1.1-2.2]$ & * & (49) \\
\hline (U)AP & $>36$ & 3,227 & $1.4[\mathrm{NR}]$ & * & $1.3[\mathrm{NR}]$ & * & $1.8[\mathrm{NR}]$ & $\star \star \star$ & $0.5[\mathrm{NR}]$ & 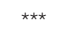 & $2.2[\mathrm{NR}]$ & 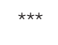 & (31) \\
\hline $\mathrm{CHD}$ & $>36$ & 942 & 0.9 [0.9-1.0] & n.s. & & & & & & & $1.1[1.1-1.2]^{\mathrm{c}}$ & $\star \star \star ~$ & (43) \\
\hline $\mathrm{CHD}$ & $>36$ & 4,535 & 1.4 [1.0-1.9] & $\mathrm{NR}$ & & & & & & & & & (35) \\
\hline Stable CAD & $>36$ & 2,370 & $1.4[0.7-2.5]$ & n.s. & & & & & & & 1.7 [1.3-2.2] & $\star \star \star$ & (37) \\
\hline Stable CAD & $>36$ & 141 & & & & & & & $2.3[1.3-3.8]^{a}$ & NR & & & $(47)$ \\
\hline $\mathrm{PCl}$ & $>36$ & 798 & & & & & & & & & 2.3 [1.3-4.3] & $\star *$ & (50) \\
\hline
\end{tabular}

The risk of major adverse cardiovascular events (MACE) in CAD patients categorized by follow-up time. The indicated risk can be a relative risk, odds ratio, or hazard rate. Unless stated otherwise, the indicated risk regards the risk of patients in the group with the highest cell count compared to patients with low cell counts. FU indicates follow-up time in months.

${ }^{a}$ Risk regarding cell percentage.

${ }^{b}$ Risk regarding $>15 \%$ urokinase-type plasminogen activator receptor-positive monocytes.

${ }^{c}$ Risk increase per $1 \times 10$ e9 cells per liter of blood or increase of 1 NLR.

${ }^{\circ}$ Lowest tertile or quartile compared to highest.

${ }^{\circ}$ Besides neutrophil count, the neutrophil percentage was also not associated with MACE risk.

${ }^{t}$ Risk score was also not related for 3 years of follow-up.

${ }^{9} \mathrm{CD} 14^{+} \mathrm{CD} 16^{++}$monocytes; total monocyte count or other subsets were not associated with MACE.

${ }^{n}$ Risk regarding $C D 4{ }^{+} C D 28$ null $T$ cell frequency $>4 \%$.

The level of significance in multivariate analyses is indicated by ${ }^{*} p<0.05 ;{ }^{* *} p<0.01 ;{ }^{* *} p<0.001$; n.s. indicates not significant.

and differ in function (53). Classical $\mathrm{CD} 14^{++} \mathrm{CD} 16^{-}$monocytes are predominantly phagocytic, non-classical $\mathrm{CD} 14^{+} \mathrm{CD} 16^{++}$ monocytes display mainly inflammatory characteristics, and a small transitional subset of intermediate $\mathrm{CD} 14^{+} \mathrm{CD} 16^{+}$monocytes displays both phagocytic and inflammatory function (54). In a few studies exploring the prognostic power of total monocytes, no evidence for monocytes as independent predictors of recurrent cardiovascular events could be established (38, 39). However, others report that elevated monocyte count is a significant predictor for secondary cardiovascular manifestations and mortality increasing the average risk by $50 \%(30,31$, $40,42,45)$. This has been shown to be primarily associated with the $\mathrm{CD} 14^{+} \mathrm{CD} 16^{++}$intermediate monocyte subtype (45) and to be dependent on follow-up time (40) (Tables 1 and 2). Another study investigating the role of monocyte activation showed that patients with high percentages of urokinase-type plasminogen activator receptor-positive monocytes, indicative of increased monocyte infiltration and activation, had increased risk of recurrent cardiovascular events (46).

\section{NEUTROPHILS}

Both under homeostatic and acute inflammatory conditions, neutrophils are the major component of the total WBC count $(\sim 60-70 \%)$. Although rarely found in human atherosclerotic plaques, experimental atherosclerosis mouse studies have shown a role for neutrophils in the initiation of atherosclerosis (55). Elevated neutrophil levels are associated with rupture prone plaques $(56,57)$ and in-stent restenosis after PCI (26). However, there is conflicting evidence about the prognostic value of neutrophils in stable CAD patients. Some reports show that elevated neutrophil count $(>6 \mathrm{G} / \mathrm{L})$ is associated with an approximately doubled risk of mortality or MACE $(30,31,33)$. Others could not establish this prognostic value of neutrophils $(38-40,42)$ (Tables 1 and 2). The studies that showed an independent prognostic value of neutrophils were more likely to include PCI and AP patients instead of CAD patients, and to have MACE as endpoint rather than mortality. This suggests that, also in the setting of CVD, neutrophils are mostly related to an acute inflammatory 
reaction upon cardiac injury rather than the chronic inflammatory response in plaque development.

\section{LYMPHOCYTES}

The role of lymphocytes in CVD has been extensively investigated in experimental atherosclerosis models. A plethora of different B- and T-cell subtypes with both atherogenic or atheroprotective roles has been reported (reviewed in Ref. 58). However, in the human setting, the evidence for a lymphocyte specific role in the presentation of atherosclerosis is limited and the outcome remains inconclusive. The majority of studies showed that high lymphocyte counts were not independently associated with plaque progression, in-stent restenosis, CVD events, or mortality $(24,26,30,38,40)$, while there is only one study that reports on high levels of lymphocytes being protective for future events (31) (Tables 1 and 2). Another group observed a role for a specific $\mathrm{T}$ lymphocyte subset, as the increase of $\mathrm{CD} 4^{+} \mathrm{CD} 28^{\text {null }}$ $\mathrm{T}$ cells was associated with increased rate of CVD events (48) (Table 2). These $\mathrm{CD} 4{ }^{+} \mathrm{CD} 28^{\text {null }}$ cells have profound effector functions and are considered to be pro-atherogenic as their levels are high in unstable, but not in stable plaques (59). When assessing lymphocytes as a percentage of the total WBC count, high lymphocyte percentages were protective of 1-year MACE in PCI patients (28). By contrast, high lymphocyte percentages showed to be detrimental in stable CAD patients for long term follow-up (3 and 13.2 years) only (47). It can be debated on whether using the percentage of WBCs is the best parameter as the relative contribution of inflammatory cell subtypes may be similar in patients with or without follow-up events. However, due to an increase in total WBC counts, the total amount of cell subtypes may very well differ between patients.

\section{NEUTROPHIL TO LYMPHOCYTE RATIO (NLR)}

The NLR is an emerging biomarker that may better reflect the immune status of an individual as compared to a single inflammatory cell subtype. In a recent study using multidetector computed tomography, NLR was shown to be associated with severity and plaque morphology in CAD patients (60). The NLR prognosticates outcome consistently in the majority of the studies performed in stable CAD patients (Tables 1 and 2). Risk of MACE or mortality increased approximately by $150 \%$ in patients with elevated NLR (average cut-off > 2.5) $(31,33,37,38,40,43$, $44,49,50)$. The exact underlying mechanisms of NLR in relation to recurrent events in CAD patients are poorly understood. Low lymphocyte counts might result from increased cortisol levels that induce apoptosis specifically in lymphocytes (and eosinophils), but increase total WBC count (61). A rise in neutrophil counts is often accompanied with increased neutrophil activity, thereby leading to the release of proteolytic enzymes, for example, myeloperoxidase, which can induce tissue injury (62). In addition, vascular obstruction as a consequence of neutrophil aggregates, a process also involving platelets and endothelial cells, increases the risk of recurrent events (63).

\section{THE PROGNOSTIC VALUE OF CIRCULATING INFLAMMATORY CELLS IN ACSS}

In patients with ACS, the rate of recurrent cardiovascular events and mortality is higher as compared to stable CAD patients. Because of the increased event rate and the differences in plaque composition $(64,65)$, the prognosis in these patients is likely to be different as well. Therefore, we consider the prognostic value of circulating cells in ACS patients separately in this chapter.

\section{WHITE BLOOD CELLS}

Similar to more general CAD populations, also in specific ACS populations contrasting results are reported for the prognostic value of WBCs. Several reports show that increased leukocyte count (on average $>12 \times 10 \mathrm{e} 9 / \mathrm{L}$ ) predicted increased MACE and mortality risk independently (approximately 2.5 times risk increase) (3,66-76). However, thesefindingswerenotcorroborated by others (77-84) (Tables 3 and 4). In general, WBC count was a better predictor in patients with short follow-up than long followup. In addition, the studies which showed a prognostic value for the WBC count had a larger sample size, which might explain the different observations in prognostic value of WBCs. How the different WBC subtypes may relate to the risk for MACE or mortality during follow-up will be discussed below.

\section{MONOCYTES}

Although monocytes play a central role in atherosclerosis, their role in risk prediction has been scarcely investigated in ACS patients (Tables 3 and 4). In one study, the three monocyte subsets were investigated over time after MI, and monocyte numbers peaked at day 2 post-MI (100). Total, CD $14^{++} \mathrm{CD} 16^{+}$classical monocytes and $\mathrm{CD}_{14}{ }^{++} \mathrm{CD} 16^{-}$non-classical monocytes, but not $\mathrm{CD} 14^{+} \mathrm{CD} 16^{++}$intermediate monocytes, were predictive for MACE when assessed 2 days post-MI. Of five different measurements over time in this study, $\mathrm{CD} 14^{++} \mathrm{CD} 16^{+}$classical monocytes were most consistently (four out of five) associated with recurrent CVD events (100). In addition, the classical CD $14^{++} \mathrm{CD} 16^{+}$monocyte was significantly associated with carotid atherosclerosis and intraplaque neovascularization (104). In two other studies, the total monocyte count did not independently prognosticate mortality $(74,83)$. Thus, there is limited and inconclusive evidence for a prognostic value of circulating monocytes for recurrent CVD events and mortality, despite the fact that monocytes are important in plaque development and rupture. The lack of a clear association may have different explanations. It can be due to the fact that mainly total monocyte numbers are used, while it has been clearly established that different monocyte subtypes exist (54). Indeed, in line with the findings in stable CAD patients, a significant association with recurrent cardiovascular events was observed in specific monocyte subsets $(45,46,100)$. On the other hand, the circulating monocyte pool may simply not reflect the macrophage pool in the plaque. Indeed, a study by Robbins and colleagues has established that plaque macrophages in a 
TABLE 3 | Mortality risk predicted by total white blood cell (WBC) and WBC differential in acute coronary syndrome (ACS) patients categorized by follow-up time.

\begin{tabular}{|c|c|c|c|c|c|c|c|c|c|c|c|c|c|}
\hline \multicolumn{3}{|c|}{ Study characteristics } & \multicolumn{2}{|l|}{ WBC } & \multicolumn{2}{|c|}{ Monocytes } & \multicolumn{2}{|c|}{ Neutrophils } & \multicolumn{2}{|c|}{ Lymphocytes } & \multicolumn{2}{|c|}{$\begin{array}{l}\text { Neutrophil to } \\
\text { lymphocyte ratio }\end{array}$} & \multirow[t]{2}{*}{ Reference } \\
\hline Population & FU & Size $(n)$ & $\begin{array}{c}\text { Risk } \\
{[95 \% \mathrm{Cl}]}\end{array}$ & $p$ & $\begin{array}{c}\text { Risk } \\
{[95 \% \mathrm{Cl}]}\end{array}$ & $p$ & $\begin{array}{c}\text { Risk } \\
{[95 \% \mathrm{Cl}]}\end{array}$ & $p$ & $\begin{array}{c}\text { Risk } \\
{[95 \% \mathrm{Cl}]}\end{array}$ & $p$ & $\begin{array}{c}\text { Risk } \\
{[95 \% \mathrm{Cl}]}\end{array}$ & $p$ & \\
\hline AMl & $<1$ & 153,213 & $2.3[2.2-2.5]$ & $\star \star \star \star ~$ & & & & & & & & & (3) \\
\hline AMI & $<1$ & 751 & $2.3[1.2-4.5]$ & * & & & & & & & & & (66) \\
\hline AMI & $<1$ & 1,016 & $3.7[1.6-8.7]$ & $\star \star$ & & & & & & & & & (67) \\
\hline AMI & $<1$ & 115,273 & 2.7 [2.5-2.9] & $\mathrm{NR}$ & & & & & & & & & (68) \\
\hline AMI & $<1$ & 2,863 & $1.6[1.1-2.5]$ & $\star \star$ & & & & & & & & & (76) \\
\hline STEMI & $<1$ & 305 & & & & & $4.6[1.5-14.4]^{a}$ & * & & & & & (85) \\
\hline STEMI & $<1$ & 404 & & & & & $2.9[1.0-8.4]$ & * & & & & & (86) \\
\hline STEMI + pPCl & $<1$ & 304 & & & & & & & & & $1.1[1.0-1.2]$ & n.s. & (87) \\
\hline STEMI & $<1$ & 522 & & & & & & & & & $3.8[1.7-8.3]$ & $\star \star$ & (88) \\
\hline ACS & $<1$ & 2,833 & & & & & & & & & $2.0[1.2-3.6]$ & * & (89) \\
\hline STEMI & $<1$ & 636 & & & & & & & & & $2.4[1.3-4.4]$ & n.s. & (90) \\
\hline STEMI + PCl & $<1$ & 538 & & & & & & & & & $15.8[1.6-154]$ & * & (91) \\
\hline ACS & $1-6$ & 2,833 & & & & & & & & & $3.9[3.2-8.1]$ & $\star * \star *$ & (89) \\
\hline STEMI & $>6-36$ & 470 & $2.5[1.3-4.9]$ & NR & $1.8[1.0-3.4]$ & $N R$ & $2.2[1.2-4.3]$ & NR & $0.4[0.2-1.0]$ & NR & $4.2[1.7-10.2]$ & $\star \star$ & (74) \\
\hline AMI & $>6-36$ & 1,016 & $2.9[1.2-7.1]$ & * & & & & & & & & & (67) \\
\hline $\mathrm{ACS}+\mathrm{PCl}$ & $>6-36$ & 4,329 & $1.1[1.0-1.1]^{\mathrm{b}}$ & $\star \star \star$ & & & & & & & & & (70) \\
\hline $\mathrm{pPCl}$ & $>6-36$ & 958 & $1.1[1.0-1.2]^{\mathrm{b}, \mathrm{d}}$ & NR & & & & & & & & & (71) \\
\hline AMI & $>6-36$ & 447 & NR & n.s. & & & & & & & & & (81) \\
\hline NSTE ACS & $>6-36$ & 1,315 & $1.5[1.1-2.0]$ & * & & & & & & & & & (72) \\
\hline $\mathrm{Ml}$ & $>6-36$ & 2,047 & & & & & $2.3[1.8-2.8]$ &  & & & & & (86) \\
\hline STEMI + pPCl & $>6-36$ & 304 & & & & & & & & & $1.1[1.1-1.2]$ & n.s. & (87) \\
\hline STEMI + pPCI & $>6-36$ & 210 & & & & & & & & & $2.7[1.0-7.2]$ & * & (92) \\
\hline STEMI + PCl & $>6-36$ & 325 & & & & & & & & & $3.1[1.1-8.6]$ & * & (93) \\
\hline NSTEMI & $>36$ & 619 & $1.0[0.9-1.2]$ & n.s. & $0.1[0.0-1.1]$ & n.s. & $1.0[0.9-1.2]$ & n.s. & $0.6[0.2-1.7]$ & n.s. & $1.1[1.0-1.1]$ & $\star \star$ & (83) \\
\hline STEMI & $>36$ & 458 & $1.6[1.1-2.3]$ & $\star \star$ & & & & & & & & & (73) \\
\hline NSTE-ACS & $>36$ & 476 & $2.0[1.4-2.7]$ & $\star \star \star$ & & & & & & & & & (73) \\
\hline AMl & $>36$ & 144 & 1.3 [NR] & n.s. & & & & & & & & & (78) \\
\hline STEMI + PCl & $>36$ & 1,377 & & & & & & & $2.4[1.3-4.7]^{\mathrm{c}}$ & $\star \star \star$ & & & (94) \\
\hline STEMI + PCl & $>36$ & 538 & & & & & & & & & $2.2[1.0-4.8]$ & * & (91) \\
\hline
\end{tabular}

The risk of mortality in ACS patients is categorized by follow-up time. The risk can be relative risk, odds ratio or hazard rate. Unless otherwise stated, the indicated risk regards the risk of patients in the group with the highest cell count compared to patients with low cell counts. FU indicates follow-up time in months.

${ }^{a}$ Risk regarding cell percentage.

${ }^{b}$ Risk increase per $1 \times 10$ e9 cells per liter of blood.

'Lowest tertile or quartile compared to highest.

${ }^{d}$ The presented risk score is not significant for both 1 and 2.6 years of follow-up.

The level of significance in multivariate analyses is indicated by ${ }^{*} p<0.05 ;{ }^{* *} p<0.01 ;{ }^{* *} p<0.001$; n.s. indicates not significant.

murine atherosclerosis model mostly derive from proliferation of the existing macrophage pool rather than recruitment of new monocytes (105). Furthermore, besides technical issues such as different gating strategies or isolation methods, monocyte plasticity could also explain why the circulating monocytes do not per se mirror plaque macrophages. Indeed, experimental evidence indicates that plaque macrophages can switch phenotype over time in advanced atherosclerotic lesions $(106,107)$.

\section{NEUTROPHILS}

As described in CAD patients, conflicting reports were published about the prognostic value of neutrophil counts. In ACS patients, the results are also not uniform, though more positive. Two studies were unable to establish an independent predictive value for neutrophil counts $(83,84)$. However, in the majority of the studies assessing the prognostic value of neutrophils, their counts significantly predicted short term, i.e., <30 days, (average OR 5) $(85,86,95)$ and long term, i.e., 3 years, (average $\operatorname{HR} 1.75)(74,103,108)$ secondary cardiovascular events and mortality (Tables 3 and 4). Although different studies have described that elevated neutrophil counts associate with worse outcome, it is surprising that there is no consistent evidence. Elevated neutrophil counts have been associated with endothelial disruption as a consequence of released reactive oxygen species and MPO (62). In addition, neutrophils can induce vascular plugging, thereby extending infarct size (63). The relative neutrophil count (as percentage of total WBC) might add prognostic value, but only few studies have examined their predictive power. However, the NLR described later in this review has been studied extensively.

\section{LYMPHOCYTES}

There is limited evidence for a role of total lymphocytes in risk prediction of ACS patients. Total lymphocyte counts were not independently associated with follow-up events and mortality 
TABLE 4 | Cardiovascular events predicted by total white blood cell (WBC) and WBC differential in acute coronary syndrome (ACS) patients categorized by follow-up time.

\begin{tabular}{|c|c|c|c|c|c|c|c|c|c|c|c|c|c|}
\hline \multicolumn{3}{|c|}{ Study characteristics } & \multicolumn{2}{|l|}{ WBC } & \multicolumn{2}{|l|}{ Monocytes } & \multicolumn{2}{|c|}{ Neutrophils } & \multicolumn{2}{|c|}{ Lymphocytes } & \multicolumn{2}{|c|}{$\begin{array}{l}\text { Neutrophil to } \\
\text { lymphocyte ratio }\end{array}$} & \multirow[t]{2}{*}{ Reference } \\
\hline Population & FU & Size $(n)$ & $\begin{array}{c}\text { Risk } \\
{[95 \% \mathrm{Cl}]}\end{array}$ & $p$ & $\begin{array}{c}\text { Risk } \\
{[95 \% \mathrm{Cl}]}\end{array}$ & $p$ & $\begin{array}{c}\text { Risk } \\
{[95 \% \mathrm{Cl}]}\end{array}$ & $p$ & $\begin{array}{c}\text { Risk } \\
{[95 \% \mathrm{Cl}]}\end{array}$ & $p$ & $\begin{array}{c}\text { Risk } \\
{[95 \% \mathrm{Cl}]}\end{array}$ & $p$ & \\
\hline AMl & $<1$ & 1,016 & $2.0[1.1-3.6]$ & * & & & & & & & & & $(67)$ \\
\hline $\mathrm{pPCl}$ & $<1$ & 80 & $1.3[1.0-1.5]^{\mathrm{b}}$ & * & & & & & & & & & (69) \\
\hline ACS/nSTEMI & $<1$ & 352 & $2.5[1.4-5.7]$ & n.s. & & & & & & & & & (80) \\
\hline AMI & $<1$ & 177 & $1.0[1.0-1.1]$ & n.s. & & & & & & & & & (82) \\
\hline nSTE ACS & $<1$ & 160 & & & & & $6.5[1.6-27.2]$ & * & & & & & (95) \\
\hline $\mathrm{AMI}+\mathrm{pPCl}$ & $<1$ & 440 & & & & & & & & & 1.3 [1.2-1.5] & * & (96) \\
\hline STEMI + pPCl & $<1$ & 304 & & & & & & & & & $1.1[1.0-1.6]$ & n.s. & (87) \\
\hline STEMI & $<1$ & 682 & & & & & & & & & $1.2[1.0-1.3]$ & 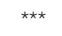 & (97) \\
\hline STEMI & $<1$ & 101 & & & & & & & & & $3.6[1.2-10.7]$ & * & (98) \\
\hline STEMI + pPCl & $<1$ & 170 & & & & & & & & & $1.2[1.0-1.3]$ & * & (99) \\
\hline ACS & $>6-36^{c}$ & 2,661 & $0.9[0.9-1.0]$ & n.s. & & & $1.0[0.8-1.0]$ & n.s. & $0.9[0.8-1.0]$ & n.s. & & & (84) \\
\hline STEMI + PCl & $>6-36$ & 331 & $2.4[1.4-4.3]$ & $\star \star$ & & & & & & & $3.8[2.2-6.7]$ & 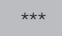 & (75) \\
\hline $\mathrm{Ml}$ & $>6-36$ & 107 & NR & n.s. & & & & & & & & & (78) \\
\hline Ml & $>6-36$ & 64 & $0.4[0.2-2.1]$ & n.s. & & & & & & & & & (79) \\
\hline STEMI & $>6-36$ & 100 & & & $3.6[1.2-10.8]^{d}$ & * & & & & & & & $(100)$ \\
\hline ACS & $>6-36$ & 166 & & & & & & & $1.2[1.1-1.3]^{a}$ & $\star \star$ & & & $(101)$ \\
\hline STEMI + pPCl & $>6-36$ & 304 & & & & & & & & & $1.1[1.1-1.2]$ & n.s. & $(87)$ \\
\hline STEMI + pPCl & $>6-36$ & 326 & & & & & & & & & $3.8[1.1-12.6]$ & * & $(102)$ \\
\hline STEMI & $>36$ & 1,287 & & & & & $1.3[1.2-1.3]$ & $\star \star \star$ & & & & & $(103)$ \\
\hline STEMI & $>36$ & 682 & & & & & & & & & $1.3[1.1-1.3]$ & $\star \star \star ~$ & $(97)$ \\
\hline
\end{tabular}

The risk of major adverse cardiovascular events (MACE) in ACS patients is ordered by follow-up time. The risk can be relative risk, odds ratio or hazard rate. Unless otherwise stated, the indicated risk regards patients in the group with the highest cell count compared to patients with low cell counts. FU indicates follow-up time in months.

${ }^{a}$ Risk increase regarding CD28 ${ }^{\text {null }}$ CD4 T cell percentage.

${ }^{b}$ Risk increase per $1 \times 10$ e cells per liter of blood.

${ }^{\circ}$ The presented risk is for all cell types also not significant for in-hospital MACE.

'Total monocytes, $C D 14^{++} C D 16^{-}$and $C D 14^{++} C D 16^{+}$, but not $C D 14^{+} C D 16^{++}$monocytes, were predictive when measured at post MI day 2.

The level of significance in multivariate analyses is indicated by ${ }^{*} p<0.05 ;{ }^{* *} p<0.01 ;{ }^{* *} p<0.001$; n.s. indicates not significant; NR indicates not reported.

$(74,83,84)$ except for one study, where low lymphocyte counts were predictive of mortality (94) (Tables 3 and 4). In addition, as for CAD patients, an increase of pro-atherogenic $\mathrm{CD} 4^{+} \mathrm{CD} 28^{\text {null }}$ $\mathrm{T}$ cells was associated with increased rate of recurrent CVD events (101) (Table 4). The information on the prognostic value of lymphocytes and specific lymphocyte subtypes is limited. Considering that both $\mathrm{T}$ and $\mathrm{B}$ cell subsets can have distinct proor anti-atherogenic or inflammatory characteristics $(58,109)$, the prognostic value of these specific subtypes could hold more value compared to the complete lymphocyte count. With advances made in multicolor flow cytometry the last decade (110), this research area deserves more attention in future biomarker studies.

\section{NEUTROPHIL TO LYMPHOCYTE RATIO}

Although the number of studies describing neutrophil or lymphocyte counts alone is limited and inconclusive, the NLR has been well studied during the past years (Tables 3 and 4). Similar to stable CAD patients, elevated NLR prognosticates adverse outcome in ACS patients as shown by several studies both at short term, i.e., <30 days (88, 89, 91, 97-99), and long term, i.e., $>6$ months, of follow-up $(74,75,83,89,91-93,97,102)$ with an average fourfold increased risk. Only in two studies, the NLR was not independently associated with MACE and CVD mortality
$(87,90)$. Apparently, the measurement combining neutrophil and lymphocyte counts adds significantly to the prognostic power of neutrophils or lymphocytes alone.

\section{SUMMARY AND FUTURE PERSPECTIVES}

Adequate risk assessment for patients with stable and unstable $\mathrm{CAD}$ is crucial to prevent recurrent events. Total circulating WBCs and WBC subtypes are strongly associated with risk of recurrent adverse events independently of many risk factors, both during hospitalization and up to 10 years of follow-up. Overall, elevated NLR appears to be most consistently associated with adverse outcomes in CAD and ACS patients. In comparison to the WBC count, four out of eight studies found that the prognostic value of NLR was superior $(37,38,40,83)$. The remaining four studies showed comparable prognostic power for NLR and WBC count $(31,33,74,75)$. Moreover, although limited, there is evidence that the NLR adds significantly to the prognosis assessed by existing prediction models such as the GRACE $(83,89,98)$ and TIMI (102) risk scores. Despite the fact that it should be thoroughly established that NLR has added value in existing risk prediction models like the TIMI and GRACE risk score $(111,112)$, clinical implementation of NLR can be reached relatively quickly. The NLR is an inexpensive marker and can easily be calculated from 
the WBC differentiation that is routinely analyzed in every hospital. Of note, several factors may influence the prognostic value of NLR. For instance, the NLR is higher in women below 50 years of age compared to age matched man, while in postmenopausal women, NLR is lower compared to age matched men (113). Besides, ethnical differences may also influence the WBC profile. The NLR is lower in African-Americans as compared to other ethnicities, including Caucasian, Asian, and Hispanic (114-116). Therefore, a tailored cut-off value of the NLR for age, sex and ethnicity might lead to a more accurate risk prediction.

Caution should be taken regarding the limitations of circulating cells as biomarker. Numbers of circulating inflammatory cells, or their subtypes, do not necessarily reflect the amount or phenotype of these cells in the plaque $(45,46,100,105)$. Nevertheless,

\section{REFERENCES}

1. World Health Organization. Global Status Report on Noncommunicable Diseases 2012. Geneva (2014).

2. Dutta P, Courties G, Wei Y, Leuschner F, Gorbatov R, Robbins CS, et al. Myocardial infarction accelerates atherosclerosis. Nature (2012) 487(7407):325-9. doi:10.1038/nature11260

3. Barron HV, Harr SD, Radford MJ, Wang Y, Krumholz HM. The association between white blood cell count and acute myocardial infarction mortality in patients $>$ or $=65$ years of age: findings from the cooperative cardiovascular project. J Am Coll Cardiol (2001) 38(6):1654-61. doi:10.1016/ S0735-1097(01)01613-8

4. Chung SC, Gedeborg R, Nicholas O, James S, Jeppsson A, Wolfe C, et al. Acute myocardial infarction: a comparison of short-term survival in national outcome registries in Sweden and the UK. Lancet (2014) 383(9925):1305-12. doi:10.1016/S0140-6736(13)62070-X

5. Boersma E, Pieper KS, Steyerberg EW, Wilcox RG, Chang WC, Lee KL, et al. Predictors of outcome in patients with acute coronary syndromes without persistent ST-segment elevation. Results from an international trial of 9461 patients. the PURSUIT investigators. Circulation (2000) 101(22):2557-67. doi:10.1161/01.CIR.101.22.2557

6. Eagle KA, Lim MJ, Dabbous OH, Pieper KS, Goldberg RJ, Van de Werf F, et al. A validated prediction model for all forms of acute coronary syndrome: estimating the risk of 6-month postdischarge death in an international registry. JAMA (2004) 291(22):2727-33. doi:10.1001/jama.291.22.2727

7. Milonas C, Jernberg T, Lindbäck J, Agewall S, Wallentin L, Stenestrand U, et al. Effect of angiotensin-converting enzyme inhibition on one-year mortality and frequency of repeat acute myocardial infarction in patients with acute myocardial infarction. Am J Cardiol (2010) 105(9):1229-34. doi:10.1016/j. amjcard.2009.12.032

8. Gulliksson M, Wedel H, Koster M, Svardsudd K. Hazard function and secular trends in the risk of recurrent acute myocardial infarction: 30 years of follow-up of more than 775,000 incidents. Circ Cardiovasc Qual Outcomes (2009) 2(3):178-85. doi:10.1161/CIRCOUTCOMES.108.802397

9. Hansson GK, Libby P, Tabas I. Inflammation and plaque vulnerability. J Intern Med (2015) 278(5):483-93. doi:10.1111/joim.12406

10. Weber C, Noels H. Atherosclerosis: current pathogenesis and therapeutic options. Nat Med (2011) 17(11):1410-22. doi:10.1038/nm.2538

11. Libby P. Inflammation in atherosclerosis. Nature (2002) 420(6917):868-74. doi:10.1038/nature 01323

12. Woollard KJ, Geissmann F. Monocytes in atherosclerosis: subsets and functions. Nat Rev Cardiol (2010) 7(2):77-86. doi:10.1038/nrcardio.2009.228

13. Ionita MG, van den Borne P, Catanzariti LM, Moll FL, de Vries JP, Pasterkamp G, et al. High neutrophil numbers in human carotid atherosclerotic plaques are associated with characteristics of rupture-prone lesions. Arterioscler Thromb Vasc Biol (2010) 30(9):1842-8. doi:10.1161/ ATVBAHA.110.209296

14. Carr SC, Farb A, Pearce WH, Virmani R, Yao JS. Activated inflammatory cells are associated with plaque rupture in carotid artery stenosis. Surgery (1997) 122(4):757-63; discussion 763-4. doi:10.1016/S0039-6060(97)90084-2 implementation of the NLR has a great potential to identify high risk CAD and ACS patients, thereby offering opportunities for intervention and prevention of recurrent cardiovascular events.

\section{AUTHOR CONTRIBUTIONS}

JM and MW designed and drafted the manuscript; IH and SJ designed and revised the manuscript.

\section{FUNDING}

This study was funded by the European Commission under the Seventh Framework (FP7-INNOVATION I HEALTH-F22013-602114-Athero-B-Cell).

15. Kovanen PT, Kaartinen M, Paavonen T. Infiltrates of activated mast cells at the site of coronary atheromatous erosion or rupture in myocardial infarction. Circulation (1995) 92(5):1084-8. doi:10.1161/01.CIR. 92.5.1084

16. Rock KL, Kono H. The inflammatory response to cell death. Annu Rev Pathol (2008) 3:99-126. doi:10.1146/annurev.pathmechdis.3.121806.151456

17. Tabas I. Consequences and therapeutic implications of macrophage apoptosis in atherosclerosis: the importance of lesion stage and phagocytic efficiency. Arterioscler Thromb Vasc Biol (2005) 25(11):2255-64. doi:10.1161/01. ATV.0000184783.04864.9f

18. Martinet W, Schrijvers DM, De Meyer GR. Necrotic cell death in atherosclerosis. Basic Res Cardiol (2011) 106(5):749-60. doi:10.1007/ s00395-011-0192-x

19. Morrow DA. Cardiovascular risk prediction in patients with stable and unstable coronary heart disease. Circulation (2010) 121(24):2681-91. doi:10.1161/ CIRCULATIONAHA.109.852749

20. Grimm RH Jr, Neaton JD, Ludwig W. Prognostic importance of the white blood cell count for coronary, cancer, and all-cause mortality. JAMA (1985) 254(14):1932-7. doi:10.1001/jama.254.14.1932

21. Thomsen M, Dahl M, Lange P, Vestbo J, Nordestgaard BG. Inflammatory biomarkers and comorbidities in chronic obstructive pulmonary disease. Am J Respir Crit Care Med (2012) 186(10):982-8. doi:10.1164/ rccm.201206-1113OC

22. Durante A, Bronzato $S$. The increased cardiovascular risk in patients affected by autoimmune diseases: review of the various manifestations. J Clin Med Res (2015) 7(6):379-84. doi:10.14740/jocmr2122w

23. Raffel OC, Tearney GJ, Gauthier DD, Halpern EF, Bouma BE, Jang IK. Relationship between a systemic inflammatory marker, plaque inflammation, and plaque characteristics determined by intravascular optical coherence tomography. Arterioscler Thromb Vasc Biol (2007) 27(8):1820-7. doi:10.1161/ ATVBAHA.107.145987

24. Nozawa N, Hibi K, Endo M, Sugano T, Ebina T, Kosuge M, et al. Association between circulating monocytes and coronary plaque progression in patients with acute myocardial infarction. Circ J (2010) 74(7):1384-91. doi:10.1253/ circj.CJ-09-0779

25. Ates AH, Canpolat U, Yorgun H, Kaya EB, Sunman H, Demiri E, et al. Total white blood cell count is associated with the presence, severity and extent of coronary atherosclerosis detected by dual-source multislice computed tomographic coronary angiography. Cardiol J (2011) 18(4):371-7.

26. Bolca O, Güngör B, Özcan KS, Karadeniz FÖ, Sungur A, Köroğlu B, et al. The neutrophil-to-lymphocyte ratio is associated with bare-metal stent restenosis in STEMI patients treated with primary PCI. Coron Artery Dis (2015) 26(5):402-8. doi:10.1097/MCA.0000000000000254

27. Lee WC, Tsai TH, Chen YL, Yang CH, Chen SM, Chen CJ, et al. Safety and feasibility of coronary stenting in unprotected left main coronary artery disease in the real world clinical practice - a single center experience. PLoS One (2014) 9(10):e109281. doi:10.1371/journal.pone.0109281

28. Bian C, Wu Y, Shi Y, Xu G, Wang J, Xiang M, et al. Predictive value of the relative lymphocyte count in coronary heart disease. Heart Vessels (2010) 25(6):469-73. doi:10.1007/s00380-010-0010-7 
29. Palmerini T, Marzocchi A, Marrozzini C, Ortolani P, Saia F, Bacchi-Reggiani L, et al. Preprocedural levels of C-reactive protein and leukocyte counts predict 9-month mortality after coronary angioplasty for the treatment of unprotected left main coronary artery stenosis. Circulation (2005) 112(15):2332-8. doi:10.1161/CIRCULATIONAHA.105.551648

30. Grau AJ, Boddy AW, Dukovic DA, Buggle F, Lichy C, Brandt T, et al. Leukocyte count as an independent predictor of recurrent ischemic events. Stroke (2004) 35(5):1147-52. doi:10.1161/01.STR.0000124122.71702.64

31. Horne BD, Anderson JL, John JM, Weaver A, Bair TL, Jensen KR, et al. Which white blood cell subtypes predict increased cardiovascular risk? J Am Coll Cardiol (2005) 45(10):1638-43. doi:10.1016/j.jacc.2005.02.054

32. Upadhya B, Applegate RJ, Sane DC, Deliargyris EN, Kutcher MA, Gandhi SK, et al. Preprocedural white blood cell count and major adverse cardiac events late after percutaneous coronary intervention in saphenous vein grafts. Am J Cardiol (2005) 96(4):515-8. doi:10.1016/j. amjcard.2005.03.103

33. Meissner J, Irfan A, Twerenbold R, Mueller S, Reiter M, Haaf P, et al. Use of neutrophil count in early diagnosis and risk stratification of AMI. Am J Med (2011) 124(6):534-42. doi:10.1016/j.amjmed.2010.10.023

34. Lloyd-Jones DM, Camargo CA, Allen LA, Giugliano RP, O’Donnell CJ. Predictors of long-term mortality after hospitalization for primary unstable angina pectoris and non-ST-elevation myocardial infarction. Am J Cardiol (2003) 92(10):1155-9. doi:10.1016/j.amjcard.2003.07.022

35. Koren-Morag N, Tanne D, Goldbourt U. White blood cell count and the incidence of ischemic stroke in coronary heart disease patients. Am J Med (2005) 118(9):1004-9. doi:10.1016/j.amjmed.2005.03.010

36. Bickel C, Rupprecht HJ, Blankenberg S, Espiniola-Klein C, Schlitt A, Rippin G, et al. Relation of markers of inflammation (C-reactive protein, fibrinogen, von willebrand factor, and leukocyte count) and statin therapy to long-term mortality in patients with angiographically proven coronary artery disease. Am J Cardiol (2002) 89(8):901-8. doi:10.1016/ S0002-9149(02)02236-1

37. Sbrana F, Cocci F, Papa A, Landi P, Sampietro T, Rossi G, et al. Routine laboratory tests to risk-stratify patients with chronic coronary artery disease. J Cardiol (2013) 61(2):132-7. doi:10.1016/j.jjcc.2012.09.005

38. Papa A, Emdin M, Passino C, Michelassi C, Battaglia D, Cocci F. Predictive value of elevated neutrophil-lymphocyte ratio on cardiac mortality in patients with stable coronary artery disease. Clin Chim Acta (2008) 395(1-2):27-31. doi:10.1016/j.cca.2008.04.019

39. Núñez J, Sanchis J, Bodí V, Núñez E, Mainar L, Heatta AM, et al. Relationship between low lymphocyte count and major cardiac events in patients with acute chest pain, a non-diagnostic electrocardiogram and normal troponin levels. Atherosclerosis (2009) 206(1):251-7. doi:10.1016/j. atherosclerosis.2009.01.029

40. Toor IS, Jaumdally R, Lip GY, Millane T, Varma C. Eosinophil count predicts mortality following percutaneous coronary intervention. Thromb Res (2012) 130(4):607-11. doi:10.1016/j.thromres.2012.05.033

41. Lloyd-Jones DM, Camargo CA Jr, Giugliano RP, O’Donnell CJ. Effect of leukocytosis at initial examination on prognosis in patients with primary unstable angina. Am Heart J (2000) 139(5):867-73. doi:10.1016/ S0002-8703(00)90019-X

42. Yamamoto E, Sugiyama S, Hirata Y, Tokitsu T, Tabata N, Fujisue K, et al. Prognostic significance of circulating leukocyte subtype counts in patients with coronary artery disease. Atherosclerosis (2016) 255:210-6. doi:10.1016/j. atherosclerosis.2016.08.033

43. Yu C, Chen M, Chen Z, Lu G. Predictive and prognostic value of admission neutrophil-to-lymphocyte ratio in patients with CHD. Herz (2016) 41(7): 605-13. doi:10.1007/s00059-015-4399-8

44. Duffy BK, Gurm HS, Rajagopal V, Gupta R, Ellis SG, Bhatt DL. Usefulness of an elevated neutrophil to lymphocyte ratio in predicting long-term mortality after percutaneous coronary intervention. Am J Cardiol (2006) 97(7):993-6. doi:10.1016/j.amjcard.2005.10.034

45. Rogacev KS, Cremers B, Zawada AM, Seiler S, Binder N, Ege P, et al. CD14++CD16+ monocytes independently predict cardiovascular events: a cohort study of 951 patients referred for elective coronary angiography. J Am Coll Cardiol (2012) 60(16):1512-20. doi:10.1016/j.jacc.2012.07.019

46. Zhang Y, Chen W, Chen LF, Wang X, Hsu J, Fang LG, et al. Increased urokinase-type plasminogen activator receptor expression on circulating monocytes is correlated with clinical instability and long-term adverse cardiac events in patients with coronary artery disease. Cardiology (2016) 135(2):98-107. doi:10.1159/000446392

47. Niessner A, Graf S, Nikfardjam M, Lehr S, Maurer G, Wojta J, et al. The adaptive immune system and long-term outcome in patients with stable coronary disease. Predictive value of routine laboratory measurements. Thromb Haemost (2005) 93(2):257-60. doi:10.1160/TH04-07-0449

48. Liuzzo G, Biasucci LM, Trotta G, Brugaletta S, Pinnelli M, Digianuario G, et al. Unusual CD4+CD28null T lymphocytes and recurrence of acute coronary events. J Am Coll Cardiol (2007) 50(15):1450-8. doi:10.1016/j.jacc.2007.06.040

49. Arbel Y, Finkelstein A, Halkin A, Birati EY, Revivo M, Zuzut M, et al. Neutrophil/lymphocyte ratio is related to the severity of coronary artery disease and clinical outcome in patients undergoing angiography. Atherosclerosis (2012) 225(2):456-60. doi:10.1016/j.atherosclerosis.2012.09.009

50. Cho KI, Ann SH, Singh GB, Her AY, Shin ES. Combined usefulness of the platelet-to-lymphocyte ratio and the neutrophil-to-lymphocyte ratio in predicting the long-term adverse events in patients who have undergone percutaneous coronary intervention with a drug-eluting stent. PLoS One (2015) 10(7):e0133934. doi:10.1371/journal.pone.0133934

51. Hristov M, Weber C. Differential role of monocyte subsets in atherosclerosis. Thromb Haemost (2011) 106(5):757-62. doi:10.1160/TH11-07-0500

52. Hristov M, Heine GH. Monocyte subsets in atherosclerosis. Hamostaseologie (2015) 35(2):105-12. doi:10.5482/HAMO-14-08-0030

53. Weber C, Shantsila E, Hristov M, Caligiuri G, Guzik T, Heine GH, et al. Role and analysis of monocyte subsets in cardiovascular disease. Joint consensus document of the European Society of Cardiology (ESC) working groups "atherosclerosis \& vascular biology" and "thrombosis". Thromb Haemost (2016) 116(4):626-37. doi:10.1160/TH16-02-0091

54. Mukherjee R, Kanti Barman P, Kumar Thatoi P, Tripathy R, Kumar Das B, Ravindran B. Non-classical monocytes display inflammatory features: validation in sepsis and systemic lupus erythematous. Sci Rep (2015) 5:13886. doi:10.1038/srep13886

55. Drechsler M, Megens RT, van Zandvoort M, Weber C, Soehnlein O. Hyperlipidemia-triggered neutrophilia promotes early atherosclerosis. Circulation (2010) 122(18):1837-45. doi:10.1161/CIRCULATIONAHA. 110.961714

56. Sasaki T, Kuzuya M, Nakamura K, Cheng XW, Shibata T, Sato K, et al. A simple method of plaque rupture induction in apolipoprotein E-deficient mice. Arterioscler Thromb Vasc Biol (2006) 26(6):1304-9. doi:10.1161/01. ATV.0000219687.71607.f7

57. van Leeuwen M, Gijbels MJ, Duijvestijn A, Smook M, van de Gaar MJ, Heeringa P, et al. Accumulation of myeloperoxidase-positive neutrophils in atherosclerotic lesions in LDLR-/- mice. Arterioscler Thromb Vasc Biol (2008) 28(1):84-9. doi:10.1161/ATVBAHA.107.154807

58. Ketelhuth DF, Hansson GK. Adaptive response of T and B cells in atherosclerosis. Circ Res (2016) 118(4):668-78. doi:10.1161/CIRCRESAHA.115.306427

59. Liuzzo G, Goronzy JJ, Yang H, Kopecky SL, Holmes DR, Frye RL, et al. Monoclonal T-cell proliferation and plaque instability in acute coronary syndromes. Circulation (2000) 101(25):2883-8. doi:10.1161/01.CIR.101.25.2883

60. Ateş AH, Aytemir K, Koçyiğit D, Yalcin MU, Gürses KM, Yorgun H, et al. Association of neutrophil-to-lymphocyte ratio with the severity and morphology of coronary atherosclerotic plaques detected by multidetector computerized tomography. Acta Cardiol Sin (2016) 32(6):676-83. doi:10.6515/ ACS20160225A

61. Nelson DH, Sandberg AA, Palmer JG, Tyler FH. Blood levels of 17-hydroxycorticosteroids following the administration of adrenal steroids and their relation to levels of circulating leukocytes. J Clin Invest (1952) 31(9):843-9. doi:10.1172/JCI102671

62. Baldus S, Heeschen C, Meinertz T, Zeiher AM, Eiserich JP, Münzel T, et al. Myeloperoxidase serum levels predict risk in patients with acute coronary syndromes. Circulation (2003) 108(12):1440-5. doi:10.1161/01. CIR.0000090690.67322.51

63. Siminiak T, Flores NA, Sheridan DJ. Neutrophil interactions with endothelium and platelets: possible role in the development of cardiovascular injury. Eur Heart J (1995) 16(2):160-70. doi:10.1093/oxfordjournals.eurheartj.a060880

64. Hoffmann U, Moselewski F, Nieman K, Jang IK, Ferencik M, Rahman AM, et al. Noninvasive assessment of plaque morphology and composition in culprit and stable lesions in acute coronary syndrome and stable lesions in stable angina by multidetector computed tomography. JAm Coll Cardiol (2006) 47(8):1655-62. doi:10.1016/j.jacc.2006.01.041 
65. Hong YJ, Jeong MH, Choi YH, Park SY, Rhew SH, Jeong HC, et al. Comparison of coronary plaque components between non-culprit lesions in patients with acute coronary syndrome and target lesions in patients with stable angina: virtual histology-intravascular ultrasound analysis. Korean Circ J (2013) 43(9):607-14. doi:10.4070/kcj.2013.43.9.607

66. Blasco L, Sanjuan R, Carbonell N, Solís MA, Puchades MJ, Torregrosa I, et al. Estimated glomerular filtration rate in short-risk stratification in acute myocardial infarction. Cardiorenal Med (2011) 1(2): 131-8. doi:10.1159/000327021

67. Kojima S, Sakamoto T, Ishihara M, Kimura K, Miyazaki S, Tei C, et al. The white blood cell count is an independent predictor of no-reflow and mortality following acute myocardial infarction in the coronary interventional era. Ann Med (2004) 36(2):153-60. doi:10.1080/07853890310021553

68. Grzybowski M, Welch RD, Parsons L, Ndumele CE, Chen E, Zalenski R, et al. The association between white blood cell count and acute myocardial infarction in-hospital mortality: findings from the national registry of myocardial infarction. Acad Emerg Med (2004) 11(10):1049-60. doi:10.1111/ j.1553-2712.2004.tb00676.x

69. Cetin M, Kocaman SA, Canga A, Kırbaş A, Yılmaz A, Erdoğan T, et al. Elevated serum YKL-40 level predicts myocardial reperfusion and in-hospital MACE in patients with STEMI. Herz (2013) 38(2):202-9. doi:10.1007/ s00059-012-3671-4

70. Ndrepepa G, Braun S, Iijima R, Keta D, Byrne RA, Schulz S, et al. Total leucocyte count, but not C-reactive protein, predicts 1-year mortality in patients with acute coronary syndromes treated with percutaneous coronary intervention. Clin Sci (Lond) (2009) 116(8):651-8. doi:10.1042/CS20080298

71. Kruk M, Karcz M, Przyłuski J, Bekta P, Kepka C, Kalińczuk L, et al. White blood cell count on admission and mortality in patients treated with primary percutaneous coronary intervention (ANIN myocardial infarction registry). Postepy Kardiol Interwencyjnej (2007) 3(4):193-4.

72. Taglieri N, Bacchi Reggiani ML, Palmerini T, Cinti L, Saia F, Guastaroba $\mathrm{P}$, et al. Baseline white blood cell count is an independent predictor of long-term cardiovascular mortality in patients with non-ST-segment elevation acute coronary syndrome, but it does not improve the risk classification of the GRACE score. Cardiology (2013) 124(2):97-104. doi:10.1159/000346377

73. Zairis MN, Adamopoulou EN, Manousakis SJ, Lyras AG, Bibis GP, Ampartzidou OS, et al. The impact of hs C-reactive protein and other inflammatory biomarkers on long-term cardiovascular mortality in patients with acute coronary syndromes. Atherosclerosis (2007) 194(2):397-402. doi:10.1016/j.atherosclerosis.2006.08.008

74. Núñez J, Núñez E, Bodí V, Sanchis J, Miñana G, Mainar L, et al. Usefulness of the neutrophil to lymphocyte ratio in predicting long-term mortality in ST segment elevation myocardial infarction. Am J Cardiol (2008) 101(6):747-52. doi:10.1016/j.amjcard.2007.11.004

75. Konishi T, Funayama N, Yamamoto T, Morita T, Hotta D, Nishihara H, et al. Prognostic value of eosinophil to leukocyte ratio in patients with ST-elevation myocardial infarction undergoing primary percutaneous coronary intervention. J Atheroscler Thromb (2016) 23. doi:10.5551/jat.37937

76. Furman MI, Becker RC, Yarzebski J, Savegeau J, Gore JM, Goldberg RJ. Effect of elevated leukocyte count on in-hospital mortality following acute myocardial infarction. Am JCardiol (1996) 78(8):945-8. doi:10.1016/ S0002-9149(96)00473-0

77. Agarwal SK, Singla I, Hreybe H, Saba S. Clinical predictors of late death in survivors of acute myocardial infarction. Tex Heart Inst J (2009) 36(1):24-30.

78. Marcinkowski M, Czarnecka D, Jastrzebski M, Fedak D, Kawecka-Jaszcz K. Inflammatory markers 10 weeks after myocardial infarction predict future cardiovascular events. Cardiol J (2007) 14(1):50-8.

79. Sargento L, Saldanha C, Monteiro J, Perdigao C, e Silva JM. Long-term prognostic value of protein $\mathrm{C}$ activity, erythrocyte aggregation and membrane fluidity in transmural myocardial infarction. Thromb Haemost (2005) 94(2):380-8. doi:10.1160/TH04-12-0791

80. Zahid M, Sonel AF, Kelley ME, Wall L, Whittle J, Fine MJ, et al. Effect of both elevated troponin-I and peripheral white blood cell count on prognosis in patients with suspected myocardial injury. Am J Cardiol (2005) 95(8):970-2. doi:10.1016/j.amjcard.2004.12.037

81. Lazaros G, Tsiachris D, Tousoulis D, Patialiakas A, Dimitriadis K, Roussos D, et al. In-hospital worsening renal function is an independent predictor of one-year mortality in patients with acute myocardial infarction. Int J Cardiol (2012) 155(1):97-101. doi:10.1016/j.ijcard.2010.10.024

82. Keskin O, Ulusoy RE, Kalemoglu M, Us MH, Yildirim I, Tarcin O, et al. White blood cell count and C-reactive protein predict short-term prognosis in acute myocardial infarction. J Int Med Res (2004) 32(6):646-54. doi: $10.1177 / 147323000403200610$

83. Azab B, Zaher M, Weiserbs KF, Torbey E, Lacossiere K, Gaddam S, et al. Usefulness of neutrophil to lymphocyte ratio in predicting short- and long-term mortality after non-ST-elevation myocardial infarction. Am J Cardiol (2010) 106(4):470-6. doi:10.1016/j.amjcard.2010.03.062

84. Cetin MS, Ozcan Cetin EH, Kalender E, Aydin S, Topaloglu S, Kisacik HL, et al. Monocyte to HDL cholesterol ratio predicts coronary artery disease severity and future major cardiovascular adverse events in acute coronary syndrome. Heart Lung Circ (2016) 25(11):1077-86. doi:10.1016/j.hlc. 2016.02.023

85. Fiarresga AJ, Ferreira RC, Feliciano J, Timóteo AT, Pelicano N, de Sousa L, et al. Prognostic value of neutrophil response in the era of acute myocardial infarction mechanical reperfusion. Rev Port Cardiol (2004) 23(11): 1387-96.

86. Ghaffari S, Nadiri M, Pourafkari L, Sepehrvand N, Movasagpoor A, Rahmatvand $\mathrm{N}$, et al. The predictive value of total neutrophil count and neutrophil/lymphocyte ratio in predicting in-hospital mortality and complications after STEMI. J Cardiovasc Thorac Res (2014) 6(1):35-41. doi:10.5681/ jcvtr.2014.007

87. Toprak C, Tabakci MM, Simsek Z, Arslantas U, Durmus HI, Ocal L, et al. Platelet/lymphocyte ratio was associated with impaired myocardial perfusion and both in-hospital and long-term adverse outcome in patients with ST-segment elevation acute myocardial infarction undergoing primary coronary intervention. Postepy Kardiol Interwencyjnej (2015) 11(4):288-97. doi:10.5114/pwki.2015.55599

88. Gazi E, Bayram B, Gazi S, Temiz A, Kirilmaz B, Altun B, et al. Prognostic value of the neutrophil-lymphocyte ratio in patients with ST-elevated acute myocardial infarction. Clin Appl Thromb Hemost (2015) 21(2):155-9. doi:10.1177/1076029613492011

89. Tamhane UU, Aneja S, Montgomery D, Rogers EK, Eagle KA, Gurm HS. Association between admission neutrophil to lymphocyte ratio and outcomes in patients with acute coronary syndrome. Am J Cardiol (2008) 102(6):653-7. doi:10.1016/j.amjcard.2008.05.006

90. Temiz A, Gazi E, Güngör Ö, Barutçu A, Altun B, Bekler A, et al. Platelet/ lymphocyte ratio and risk of in-hospital mortality in patients with ST-elevated myocardial infarction. Med Sci Monit (2014) 20:660-5. doi:10.12659/ MSM.890152

91. Arbel Y, Shacham Y, Ziv-Baran T, Laufer Perl M, Finkelstein A, Halkin A, et al. Higher neutrophil/lymphocyte ratio is related to lower ejection fraction and higher long-term all-cause mortality in ST-elevation myocardial infarction patients. Can J Cardiol (2014) 30(10):1177-82. doi:10.1016/j. cjca.2014.05.010

92. Soylu K, Yuksel S, Gulel O, Erbay AR, Meric M, Zengin H, et al. The relationship of coronary flow to neutrophil/lymphocyte ratio in patients undergoing primary percutaneous coronary intervention. J Thorac Dis (2013) 5(3):258-64. doi:10.3978/j.issn.2072-1439.2013.05.13

93. Park JJ, Jang HJ, Oh IY, Yoon CH, Suh JW, Cho YS, et al. Prognostic value of neutrophil to lymphocyte ratio in patients presenting with ST-elevation myocardial infarction undergoing primary percutaneous coronary intervention. Am J Cardiol (2013) 111(5):636-42. doi:10.1016/j.amjcard.2012.11.012

94. Boag SE, Das R, Shmeleva EV, Bagnall A, Egred M, Howard N, et al. T lymphocytes and fractalkine contribute to myocardial ischemia/reperfusion injury in patients. J Clin Invest (2015) 125(8):3063-76. doi:10.1172/JCI80055

95. Karabinos I, Koulouris S, Kranidis A, Pastromas S, Exadaktylos N, Kalofoutis A. Neutrophil count on admission predicts major in-hospital events in patients with a non-ST-segment elevation acute coronary syndrome. Clin Cardiol (2009) 32(10):561-8. doi:10.1002/clc.20624

96. Ayça B, Akin F, Çelik Ö, Yüksel Y, Öztürk D, Tekiner F, et al. Platelet to lymphocyte ratio as a prognostic marker in primary percutaneous coronary intervention. Platelets (2015) 26(7):638-44. doi:10.3109/09537104.2014. 968117

97. Kaya MG, Akpek M, Lam YY, Yarlioglues M, Celik T, Gunebakmaz O, et al. Prognostic value of neutrophil/lymphocyte ratio in patients with ST-elevated 
myocardial infarction undergoing primary coronary intervention: a prospective, multicenter study. Int J Cardiol (2013) 168(2):1154-9. doi:10.1016/j. ijcard.2012.11.074

98. Oncel RC, Ucar M, Karakas MS, Akdemir B, Yanikoglu A, Gulcan AR, et al. Relation of neutrophil-to-lymphocyte ratio with GRACE risk score to in-hospital cardiac events in patients with ST-segment elevated myocardial infarction. Clin Appl Thromb Hemost (2015) 21(4):383-8. doi:10.1177/ 1076029613505763

99. Topuz M, Oz F, Akkus O, Sen O, Topuz AN, Bulut A, et al. Plasma apelin-12 levels may predict in-hospital major adverse cardiac events in ST-elevation myocardial infarction and the relationship between apelin-12 and the neutrophil/lymphocyte ratio in patients undergoing primary coronary intervention. Perfusion (2016) 32(3):206-13. doi:10.1177/0267659116676335

100. Zhou X, Liu XL, Ji WJ, Liu JX, Guo ZZ, Ren D, et al. The kinetics of circulating monocyte subsets and monocyte-platelet aggregates in the acute phase of ST-elevation myocardial infarction: associations with 2-year cardiovascular events. Medicine (Baltimore) (2016) 95(18):e3466. doi:10.1097/ MD. 0000000000003466

101. Giubilato S, Liuzzo G, Brugaletta S, Pitocco D, Graziani F, Smaldone C, et al. Expansion of CD4+CD28null T-lymphocytes in diabetic patients: exploring new pathogenetic mechanisms of increased cardiovascular risk in diabetes mellitus. Eur Heart J (2011) 32(10):1214-26. doi:10.1093/eurheartj/ehq499

102. Han YC, Yang TH, Kim DI, Jin HY, Chung SR, Seo JS, et al. Neutrophil to lymphocyte ratio predicts long-term clinical outcomes in patients with ST-segment elevation myocardial infarction undergoing primary percutaneous coronary intervention. Korean Circ J (2013) 43(2):93-9. doi:10.4070/ kcj.2013.43.2.93

103. Zhang S, Wan Z, Zhang Y, Fan Y, Gu W, Li F, et al. Neutrophil count improves the GRACE risk score prediction of clinical outcomes in patients with ST-elevation myocardial infarction. Atherosclerosis (2015) 241(2):723-8. doi:10.1016/j.atherosclerosis.2015.06.035

104. Jaipersad AS, Shantsila A, Lip GY, Shantsila E. Expression of monocyte subsets and angiogenic markers in relation to carotid plaque neovascularization in patients with pre-existing coronary artery disease and carotid stenosis. Ann Med (2014) 46(7):530-8. doi:10.3109/07853890.2014.931101

105. Robbins CS, Hilgendorf I, Weber GF, Theurl I, Iwamoto Y, Figueiredo JL, et al. Local proliferation dominates lesional macrophage accumulation in atherosclerosis. Nat Med (2013) 19(9):1166-72. doi:10.1038/nm.3258

106. Khallou-Laschet J, Varthaman A, Fornasa G, Compain C, Gaston AT, Clement $\mathrm{M}$, et al. Macrophage plasticity in experimental atherosclerosis. PLoS One (2010) 5(1):e8852. doi:10.1371/journal.pone.0008852

107. Moore K, Sheedy F, Fisher E. Macrophages in atherosclerosis: a dynamic balance. Nat Rev Immunol (2013) 13(10):709-21. doi:10.1038/nri3520

108. Arruda-Olson AM, Reeder GS, Bell MR, Weston SA, Roger VL. Neutrophilia predicts death and heart failure after myocardial infarction: a community-based study. Circ Cardiovasc Qual Outcomes (2009) 2(6):656-62. doi:10.1161/CIRCOUTCOMES.108.831024

109. Tse K, Tse H, Sidney J, Sette A, Ley K. T cells in atherosclerosis. Int Immunol (2013) 25(11):615-22. doi:10.1093/intimm/dxt043

110. Eriksson O, Douhan Hakansson L, Karawajczyk M, Garwicz D. Neutrophil CD64 expression - comparison of two different flow cytometry protocols on EPICs MCL and the Leuko64() assay on a celldyn sapphire haematology analyser. Scand J Clin Lab Invest (2015) 75(5):428-33. doi:10.3109/00365513. 2015.1031690

111. Morrow DA, Antman EM, Charlesworth A, Cairns R, Murphy SA, de Lemos JA, et al. TIMI risk score for ST-elevation myocardial infarction: a convenient, bedside, clinical score for risk assessment at presentation: an intravenous nPA for treatment of infarcting myocardium early II trial substudy. Circulation (2000) 102(17):2031-7. doi:10.1161/01.CIR.102.17.2031

112. Fox KA, Anderson FA Jr, Dabbous OH, Steg PG, López-Sendón J, Van de Werf $\mathrm{F}$, et al. Intervention in acute coronary syndromes: do patients undergo intervention on the basis of their risk characteristics? The global registry of acute coronary events (GRACE). Heart (2007) 93(2):177-82. doi:10.1136/ hrt.2005.084830

113. Chen Y, Zhang Y, Zhao G, Chen C, Yang P, Ye S, et al. Difference in leukocyte composition between women before and after menopausal age, and distinct sexual dimorphism. PLoS One (2016) 11(9):e0162953. doi:10.1371/journal. pone. 0162953

114. Azab B, Camacho-Rivera M, Taioli E. Average values and racial differences of neutrophil lymphocyte ratio among a nationally representative sample of united states subjects. PLoS One (2014) 9(11):e112361. doi:10.1371/journal. pone. 0112361

115. Misumida N, Kobayashi A, Kanei Y. Racial differences in the neutrophil-to-lymphocyte ratio in patients with non-ST-segment elevation myocardial infarction. Coron Artery Dis (2015) 26(5):381-5. doi:10.1097/ MCA. 0000000000000237

116. Kounis NG, Hahalis G. White blood cell counts in predicting cardiovascular events: the racial ratios. Coron Artery Dis (2015) 26(5):369-71. doi:10.1097/ MCA. 0000000000000247

Conflict of Interest Statement: The authors declare that the research was conducted in the absence of any commercial or financial relationships that could be construed as a potential conflict of interest.

Copyright $\odot 2017$ Meeuwsen, Wesseling, Hoefer and de Jager. This is an open-access article distributed under the terms of the Creative Commons Attribution License (CC $B Y)$. The use, distribution or reproduction in other forums is permitted, provided the original author(s) or licensor are credited and that the original publication in this journal is cited, in accordance with accepted academic practice. No use, distribution or reproduction is permitted which does not comply with these terms. 